\title{
Radioactive cesium accumulation in freshwater fishes after the Fukushima nuclear accident
}

\author{
Takaomi Arai
}

\begin{abstract}
The Fukushima Daiichi Nuclear Power Plant (F1NPP) accident released large amounts of radioactive substances into the environment and contaminated the terrestrial and marine ecosystems in East Japan. The unpredicted nuclear accident is of global concern for human health and ecosystems. Investigations of radionuclides in the local environments were performed shortly after the accident began; however the temporal and spatial effects and variations in the released radionuclides on the natural environment remain unclear. In the present study, three-year (May 2011 to March 2014) fluctuations and accumulations of total $\mathrm{Cs},{ }^{134} \mathrm{Cs}$ and ${ }^{137} \mathrm{Cs}$ in freshwater fishes in Fukushima prefecture after the F1NPP accident were examined. The total $\mathrm{Cs},{ }^{134} \mathrm{Cs}$ and ${ }^{137} \mathrm{Cs}$ concentrations decreased gradually during the three-year period that followed the F1NPP accident. However higher levels, i.e., exceeding $100 \mathrm{~Bq} \mathrm{~kg}^{-1}$, which is the interim limit of radiocesium level in Japan, were detected in several fish species. Radiocesium accumulation patterns in fishes in Fukushima prefecture varied between regions and corresponded to the environmental radiocesium levels in the Fukushima region. These radionuclides are widely distributed and remain in the natural environment. Moreover, a fresh input of radiocesium substances from the F1NPP site into the terrestrial environment remains.
\end{abstract}

Keywords: Fukushima nuclear accident; Radioactive contamination; Cesium; Terrestrial environment; Global deposition

\section{Introduction}

A catastrophic earthquake and tsunami occurred on March 11, 2011, which caused destruction in northeastern Japan and severely damaged the Fukushima Daiichi Nuclear Power Plant (F1NPP). The loss of power and the subsequent overheating, meltdowns, and hydrogen explosions at the F1NPP site resulted in airborne fallout over the land and the ocean that peaked in mid-March (Chino et al. 2011; Morino et al. 2011; Yasunari et al. 2011). The concentration of radionuclides reached a maximum in mid-April of 2011; however previous work has reported that the artificial release of radionuclides from the F1NPP site has continued (Kanda 2013). The F1NPP accident released a large amount of artificial radioactive fission products such as ${ }^{131} \mathrm{I},{ }^{134} \mathrm{Cs},{ }^{137} \mathrm{Cs},{ }^{239} \mathrm{Pu}$ and ${ }^{240} \mathrm{Pu}$ from the nuclear reactors into the ambient environment. The uptake of such radionuclides into human bodies is of serious concern (Travnikova et al. 2004; Rainbow 2007; Smith et al. 2009). Therefore, monitoring the long-term behaviour of radionuclides in the environment is an important

Correspondence: arai@umt.edu.my

Institute of Oceanography and Environment, Universiti Malaysia Terengganu, 21030 Kuala Terengganu, Terengganu, Malaysia issue for estimating possible radiological consequences and associated risks (Pröhl et al. 2006).

Among these radioactive fission products, the effects of ${ }^{134} \mathrm{Cs}$ and ${ }^{137} \mathrm{Cs}$ are the most serious because of their high concentrations and long decay periods (Folsom et al. 1968; Folsom and Grismore 1970; Young et al. 1975) and high bioavailability (Whicker and Schultz 1982). The physical half-lives for ${ }^{134} \mathrm{Cs}$ and ${ }^{137} \mathrm{Cs}$ are 2.07 years and 30.07 years, respectively. Because cesium and potassium have similar chemical characteristics to alkali elements, radioactive cesium can easily enter into the food chain and become an important contributor to internal radiation dosages in animal bodies, especially in muscle tissues (Peters et al. 1999; Baudin 2000; Leung and Shang 2003; Malek et al. 2004).

Fish are a major source of protein and nutrition; therefore, these species become a potential carrier of radionuclides from the aquatic environment to humans. Because radiocesium (i.e., ${ }^{134} \mathrm{Cs},{ }^{137} \mathrm{Cs}$ and the total $\mathrm{Cs}$ ) accumulates and concentrates in muscle tissues, the consumption of contaminated fish can be an important pathway for human exposure (Forseth et al. 1991; Whicker et al. 1993). Therefore, it is prudent to determine the Cs levels

\section{Springer}


in different fish species to document the prevalence of radiocesium in fish and to account for the transfer of radiocesium to humans through fish. Determining the Cs levels in fish is also important for evaluating the potential use of contaminated areas and the possible effectiveness of remediation activities. In the case of the Chernobyl Accident, the bioaccumulation of radionuclides including radiocesium in fish has been previously studied in Europe (Hakanson et al. 1989; Elliott et al. 1992; Ugedal et al. 1995). Most of the attention was focused on Belarus, the Russian Federation and Ukraine because the water bodies in these areas exhibited higher contamination levels (Mizuno and Kubo 2013). However, in the case of the F1NPP accident, little information is available on radiocesium contamination and accumulation in the local freshwater ecosystems.

Several agencies have conducted investigations to monitor the radioactive characteristics of water, soil, air and biota after the F1NPP accident; considerable data have been reported to understand the present status of radionuclide pollution levels (Buesseler et al. 2011, 2012; Chino et al. 2011; Masson et al. 2011). The Fisheries Agency of the Japanese Government is also frequently publishing the radiocesium data; these data are primarily obtained from fish samples collected since the F1NPP accident (The Fisheries Agency of the Japanese Government 2014a). Although several datasets have been published and are freely accessible, few systematic and comprehensive analyses have been performed to understand the variations and distribution of radiocesium levels in the Fukushima area. It has been three years since the F1NPP disaster; however, the radionuclide pollution issues have not yet converged. In such a situation, systematic and comprehensive investigations of radionuclides in natural environments are required.

In this study, Radiocesium (i.e., ${ }^{134} \mathrm{Cs},{ }^{137} \mathrm{Cs}$ and the total Cs) levels in 14 freshwater species from Fukushima prefecture were examined using 1007 samples collected between May 2011 and March 2014. The temporal and spatial variations of each radiocesium isotope gradually decreased during the three-year peiord. However, the present study indicates that the accumulation patterns of radiocesium in freshwater species were different among the studied species.

\section{Material and methods}

In this study, 14 freshwater fish species were examined from 44 sites in five regions of Sousou, Iwaki, Fukushima, Koriyama and Aizu in Fukushima prefecture, Japan, between May 2011 and March 2014 (The Fisheries Agency of the Japanese Government 2014a) (Figure 1 and Table 1). All radiocesium data were from the information published by the Fisheries Agency of the Japanese Government (The Fisheries Agency of the Japanese Government 2014b). With respect to the total number of data sets examined in the total Cs, ${ }^{134} \mathrm{Cs}$ and ${ }^{137} \mathrm{Cs}, 1007,483$ and 696 datasets were examined in this study, respectively. The total Cs concentrations were available between May 2011 and March 2012 in all regions; the radiocesium isotope concentrations were available for all regions during the other periods except for the Sousou region.

To monitor radiocesium levels in fish samples, the Fisheries Agency in Japan instructed local governments and other organizations to collect samples that are at least $5 \mathrm{~kg}$ for each fish species for further radiocesium analyses (The Fisheries Agency of the Japanese Government 2014a). The edible part (muscle) was usually used for measured. The present datasets have also followed this protocol. Radioactive cesium concentration in the fish samples were determined using either a gamma ray spectrometry radionuclide assay method that utilises a germanium semiconductor detector or the $\mathrm{NaI}$ scintillation spectrometer method (The Fisheries Agency of the Japanese Government 2014a). The credibility of radiocesium analyses was monitored by the daily measurement of background radiation and the periodic use of a standard radiation source for calibration. All data are depicted below according to the wet weight basis. The detection limit was usually $<10 \mathrm{~Bq} \mathrm{~kg}{ }^{-1}$.

Each radiocesium isotope concentration for each region and in each year was compared using the KruskalWallis test. The significance of the correlation coefficient and the regression slope were determined using a t-test.

\section{Results}

\section{Temporal variation in radiocesium concentrations}

The total Cs, ${ }^{134} \mathrm{Cs}$ and ${ }^{137} \mathrm{Cs}$ concentrations significantly decreased during the three-year period following the F1NPP accident $(\mathrm{F}=482-1006, \mathrm{p}<0.0001)$ (Figure 2). The highest total Cs concentration (18700 Bq kg${ }^{-1}$ ) was found in masu salmon in March 2012 from the Sousou region near the F1NPP site (Table 2 and Figure 3); such a high concentration was not found between April 2012 and March 2014. Although each radiocesium isotope concentration decreased gradually, there were still detectable amounts in freshwater fish in Fukushima prefecture that exceeded $100 \mathrm{~Bq} \mathrm{~kg}^{-1}$ (i.e. the Japanese safety limit) of ${ }^{134} \mathrm{Cs}$ and ${ }^{137} \mathrm{Cs}$ even three years after the F1NPP accident (Figure 2 and Table 2). The detection ratios of each radiocesium isotope in ayu, white-spotted char, Japanese dace, Japanese silver crucian carp, common carp, masu salmon and pond smelt in which at least 10 samples could be analysed over three-year period also decreased (Table 1). These results suggest that radiocesium accumulated in freshwater fishes in the regions surrounding Fukushima after the F1NPP accident.

\section{Spatial variations in radiocesium concentrations}

Among the five studied regions in Fukushima prefecture, nearly all sites exhibited a gradually decrease in each 

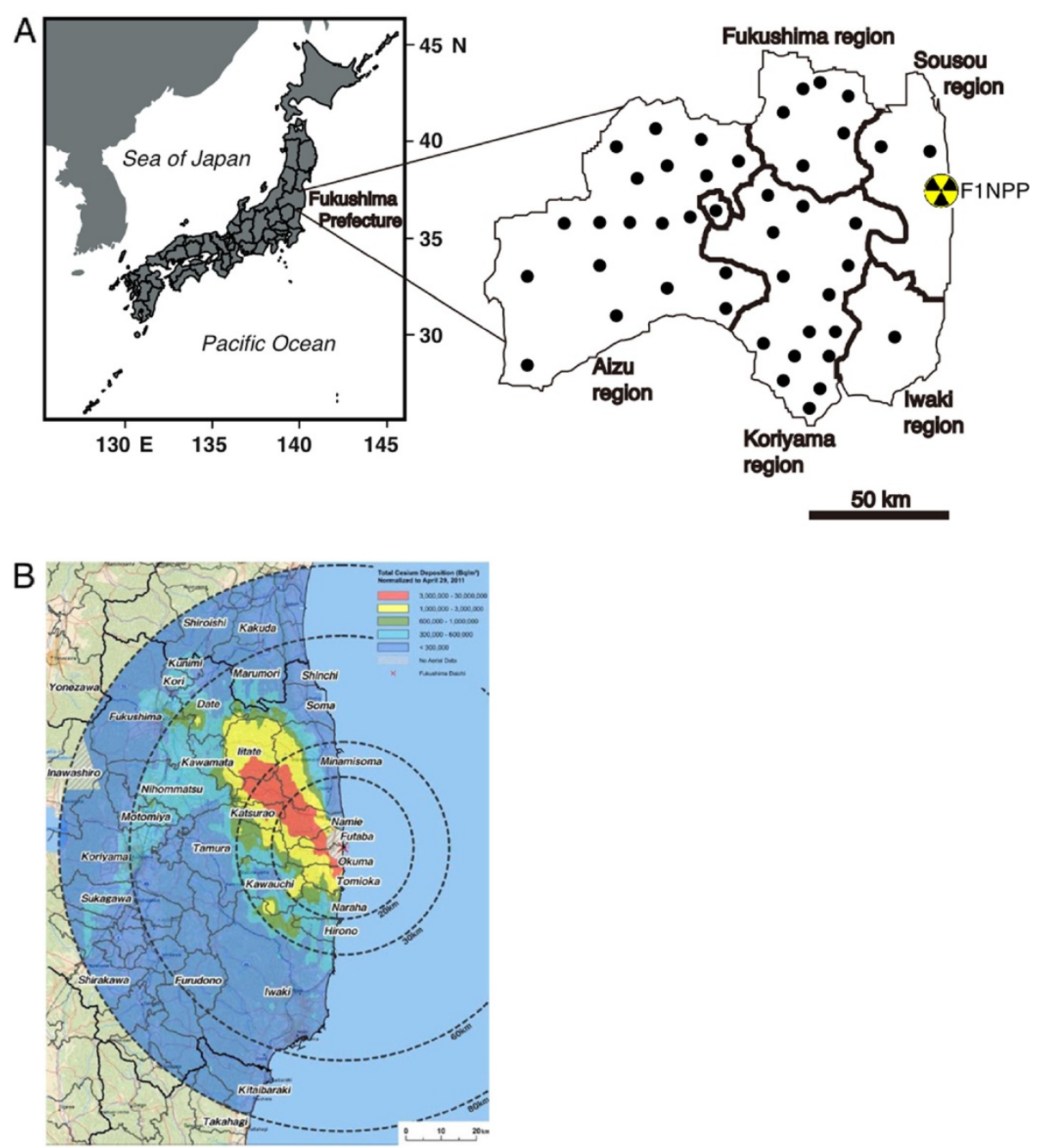

Figure 1 Study sites and horizontal distribution of radiocesium. Map showing the location of the study sites in Fukushima prefecture (A) and the deposition of radiocesium (i. e. the sum of ${ }^{134} \mathrm{Cs}$ and ${ }^{137} \mathrm{Cs}$ ) for the land area within $80 \mathrm{~km}$ of the F1NPP site, as reported by the Japanese authorities (MEXT) (B). Fukushima prefecture has five regions, i.e. the Sousou, Iwaki, Fukushima, Koriyama and Aizu regions, which are divided by thick lines on the map. Closed symbols indicate the location where samples were collected. The map of deposition of radiocesium deposition (B) was downloaded from http://www.iaea.org/newscenter/news/2011/fukushimafull.html on 2 June 2014.

radiocesium isotope concentration during the three years (Figure 3). In the Fukushima, Koriyama and Aizu regions, the total $\mathrm{Cs},{ }^{134} \mathrm{Cs}$ and ${ }^{137} \mathrm{Cs}$ concentrations decreased significantly during the three years after the F1NPP accident $(\mathrm{r}=-0.349$ to $-0.630, \mathrm{~F}=112-156, \mathrm{p}<$ 0.0001 in the Fukushima region, $r=-0.329$ to $-0.493, F=$ $68-146$, and $p<0.005-0.0001$ in the Koriyama region, and $\mathrm{r}=-0.168$ to $-0.385, \mathrm{~F}=283-642$, and $\mathrm{p}<0.005$ 0.0001 in Aizu region) (Figure 3). In the Iwaki region, a significant negative correlation was found for the total cesium concentration $(\mathrm{r}=-0.418, \mathrm{~F}=32$, and $\mathrm{p}<0.05)$, while no significant correlations were found for the ${ }^{134} \mathrm{Cs}$ and ${ }^{137} \mathrm{Cs}$ concentrations $(\mathrm{F}=3-5$ and $\mathrm{p}>0.1)$ due to the limited number of samples that were examined (Figure 3). Between May 2011 and March 2012, most of the studied fish had Cs concentrations that exceeded $1000 \mathrm{~Bq} \mathrm{~kg}{ }^{-1}$ (Figure 3) because the F1NPP site is located near this region.

The accumulation of each radiocesium isotope was different among the five regions in each year. In the Sosou, Iwaki, Fukushima, Koriyama and Aizu regions between May 2011 and March 2012, the total cesium concentrations ranged from $202 \mathrm{~Bq} \mathrm{~kg}^{-1}$ to $18700 \mathrm{~Bq} \mathrm{~kg}^{-1}$ (with a mean and standard deviation of $\left.3809 \pm 5389 \mathrm{~Bq} \mathrm{~kg}^{-1}\right)$, nd to $720 \mathrm{~Bq} \mathrm{~kg}^{-1}\left(142 \pm 172 \mathrm{~Bq} \mathrm{~kg}^{-1}\right), 89$ to $2080 \mathrm{~Bq} \mathrm{~kg}^{-1}$ $\left(747 \pm 454 \mathrm{~Bq} \mathrm{~kg}^{-1}\right)$, nd to $620 \mathrm{~Bq} \mathrm{~kg}^{-1}\left(151 \pm 140 \mathrm{~Bq} \mathrm{~kg}^{-1}\right)$ and 0 to $870 \mathrm{~Bq} \mathrm{~kg}^{-1}\left(132 \pm 153 \mathrm{~Bq} \mathrm{~kg}^{-1}\right.$ ) (Figure 4). The highest concentrations were detected in the Sousou region compared to the other four regions $(\mathrm{F}=9$ and $\mathrm{p}<0.0001)$ (Figure 4). The second higher concentrations were found 
Table 1 Radiocesium data information for freshwater fishes examined between May 2011 and March 2014 in the present study

\begin{tabular}{|c|c|c|c|c|c|c|c|c|c|c|c|c|}
\hline \multirow[t]{2}{*}{ Species } & \multirow[t]{2}{*}{$\begin{array}{l}\text { Number of analysed } \\
\text { betweeen May } 2011 \\
\text { and March } 2012\end{array}$} & \multicolumn{3}{|c|}{$\begin{array}{l}\text { Number of data above } \\
\text { detection limit betweeen } \\
\text { May } 2011 \text { and March } 2012 \\
\text { (Ratio of detectable (\%)) }\end{array}$} & \multirow[t]{2}{*}{$\begin{array}{l}\text { Number of analysed } \\
\text { betweeen April } 2012 \\
\text { and March } 2013\end{array}$} & \multicolumn{3}{|c|}{$\begin{array}{l}\text { Number of data above } \\
\text { detection limit betweeen } \\
\text { April } 2012 \text { and March } 2013 \\
\text { (Ratio of detectable (\%)) }\end{array}$} & \multirow[t]{2}{*}{$\begin{array}{l}\text { Number of analysed } \\
\text { betweeen April } 2013 \\
\text { and March } 2014\end{array}$} & \multicolumn{3}{|c|}{$\begin{array}{l}\text { Number of data above } \\
\text { detection limit betweeen } \\
\text { April } 2013 \text { and March } 2014 \\
\text { (Ratio of detectable (\%)) }\end{array}$} \\
\hline & & Total Cs* & ${ }^{134} \mathrm{Cs}$ & ${ }^{137} \mathrm{Cs}$ & & Total Cs* & ${ }^{134} \mathrm{Cs}$ & ${ }^{137} \mathrm{Cs}$ & & Total Cs* & ${ }^{134} \mathrm{Cs}$ & ${ }^{137} \mathrm{Cs}$ \\
\hline Plecoglossus altivelis & 74 & 68 & $\mathrm{n} / \mathrm{a}$ & $\mathrm{n} / \mathrm{a}$ & 59 & 29 & 24 & 28 & 49 & 24 & 15 & 24 \\
\hline (ayu) & & (91.9) & & & & $(49.2)$ & $(40.7)$ & $(47.5)$ & & $(49.0)$ & (30.6) & $(49.0)$ \\
\hline Salvelinus leucomaenis & 44 & 41 & $\mathrm{n} / \mathrm{a}$ & $\mathrm{n} / \mathrm{a}$ & 161 & 113 & 89 & 110 & 177 & 129 & 68 & 127 \\
\hline (white-spotted char) & & $(93.2)$ & & & & (70.2) & (55.3) & $(68.3)$ & & $(72.9)$ & $(38.4)$ & $(71.8)$ \\
\hline Tribolodon hakonensis & 46 & 43 & $\mathrm{n} / \mathrm{a}$ & $n / a$ & 64 & 55 & 33 & 54 & 75 & 39 & 16 & 39 \\
\hline (Japanese dace) & & (93.5) & & & & (85.9) & (51.6) & $(84.4)$ & & $(52.0)$ & (21.3) & $(52.0)$ \\
\hline Anguilla japonica & 3 & 2 & $\mathrm{n} / \mathrm{a}$ & $\mathrm{n} / \mathrm{a}$ & 3 & 3 & 3 & 3 & 2 & 2 & 2 & 2 \\
\hline (Japanese eel) & & $(66.7)$ & & & & $(100)$ & (100) & $(100)$ & & $(100)$ & $(100)$ & $(100)$ \\
\hline Carassius langsdorfii & 18 & 2 & $\mathrm{n} / \mathrm{a}$ & n/a & 13 & 13 & 13 & 13 & 17 & 16 & 14 & 16 \\
\hline (Japanese silver crucian carp) & & $(11.1)$ & & & & $(100)$ & $(100)$ & $(100)$ & & $(94.1)$ & $(82.4)$ & $(94.1)$ \\
\hline Carassius cuvieri & 3 & 3 & $\mathrm{n} / \mathrm{a}$ & $\mathrm{n} / \mathrm{a}$ & 1 & 1 & 1 & 1 & 2 & 2 & 2 & 2 \\
\hline (Japanese white crucian carp) & & $(100)$ & & & & $(100)$ & $(100)$ & $(100)$ & & $(100)$ & $(100)$ & $(100)$ \\
\hline Cyprinus carpio & 13 & 11 & $\mathrm{n} / \mathrm{a}$ & $\mathrm{n} / \mathrm{a}$ & 23 & 19 & 16 & 19 & 17 & 16 & 10 & 16 \\
\hline (common carp) & & $(84.6)$ & & & & (82.6) & (69.6) & $(82.6)$ & & $(94.1)$ & $(58.8)$ & $(94.1)$ \\
\hline Micropterus dolomieu & 5 & 5 & $\mathrm{n} / \mathrm{a}$ & $\mathrm{n} / \mathrm{a}$ & $\mathrm{n} / \mathrm{a}$ & $n / a$ & $\mathrm{n} / \mathrm{a}$ & $\mathrm{n} / \mathrm{a}$ & $n / a$ & $\mathrm{n} / \mathrm{a}$ & $\mathrm{n} / \mathrm{a}$ & $\mathrm{n} / \mathrm{a}$ \\
\hline (smallmouth bass) & & $(100)$ & & & & & & & & & & \\
\hline Misgurnus anguillicaudatu & 4 & 4 & $\mathrm{n} / \mathrm{a}$ & $\mathrm{n} / \mathrm{a}$ & 1 & 1 & 0 & 1 & 1 & 0 & 0 & 0 \\
\hline (weather loach) & & $(100)$ & & & & $(100)$ & (0) & (0) & & (0) & (0) & (0) \\
\hline Hemibarbus barbus & 2 & 2 & $\mathrm{n} / \mathrm{a}$ & $\mathrm{n} / \mathrm{a}$ & $\mathrm{n} / \mathrm{a}$ & $\mathrm{n} / \mathrm{a}$ & $\mathrm{n} / \mathrm{a}$ & $\mathrm{n} / \mathrm{a}$ & $\mathrm{n} / \mathrm{a}$ & $\mathrm{n} / \mathrm{a}$ & $n / a$ & $\mathrm{n} / \mathrm{a}$ \\
\hline (barbel steed) & & $(100)$ & & & & & & & & & & \\
\hline Oncorhynchus mykiss & 1 & 0 & $\mathrm{n} / \mathrm{a}$ & $\mathrm{n} / \mathrm{a}$ & 1 & 0 & 0 & 0 & $\mathrm{n} / \mathrm{a}$ & $\mathrm{n} / \mathrm{a}$ & $\mathrm{n} / \mathrm{a}$ & $\mathrm{n} / \mathrm{a}$ \\
\hline (rainbow trout) & & (0) & & & & (0) & (0) & (0) & & & & \\
\hline Oncorhynchus nerka & 6 & 6 & $\mathrm{n} / \mathrm{a}$ & $\mathrm{n} / \mathrm{a}$ & 10 & 10 & 10 & 10 & 17 & 17 & 17 & 17 \\
\hline (sockeye salmon) & & (100) & & & & (100) & $(100)$ & $(100)$ & & (100) & (100) & (100) \\
\hline
\end{tabular}


Table 1 Radiocesium data information for freshwater fishes examined between May 2011 and March 2014 in the present study (Continued)

\begin{tabular}{|c|c|c|c|c|c|c|c|c|c|c|c|c|}
\hline Oncorhynchus masou & 69 & 63 & $\mathrm{n} / \mathrm{a}$ & $\mathrm{n} / \mathrm{a}$ & 120 & 89 & 68 & 89 & 145 & 89 & 51 & 89 \\
\hline (masu salmon) & & $(91.3)$ & & & & $(74.2)$ & $(56.7)$ & (74.2) & & $(61.4)$ & $(35.2)$ & $(61.4)$ \\
\hline Hypomesus nipponensis & 39 & 39 & $\mathrm{n} / \mathrm{a}$ & $\mathrm{n} / \mathrm{a}$ & 29 & 26 & 25 & 26 & 13 & 11 & 6 & 11 \\
\hline (pond smelt) & & (100) & & & & (89.7) & $(86.2)$ & (89.7) & & (84.6) & (46.2) & (84.6) \\
\hline
\end{tabular}

*Total $\mathrm{Cs}={ }^{134} \mathrm{Cs}+{ }^{137} \mathrm{Cs}$.

Total Cs was available between May 2011 and March 2014

${ }^{134} \mathrm{Cs}+{ }^{137} \mathrm{Cs}$ were available between April 2012 and March 2014

n/a: not applicable. 


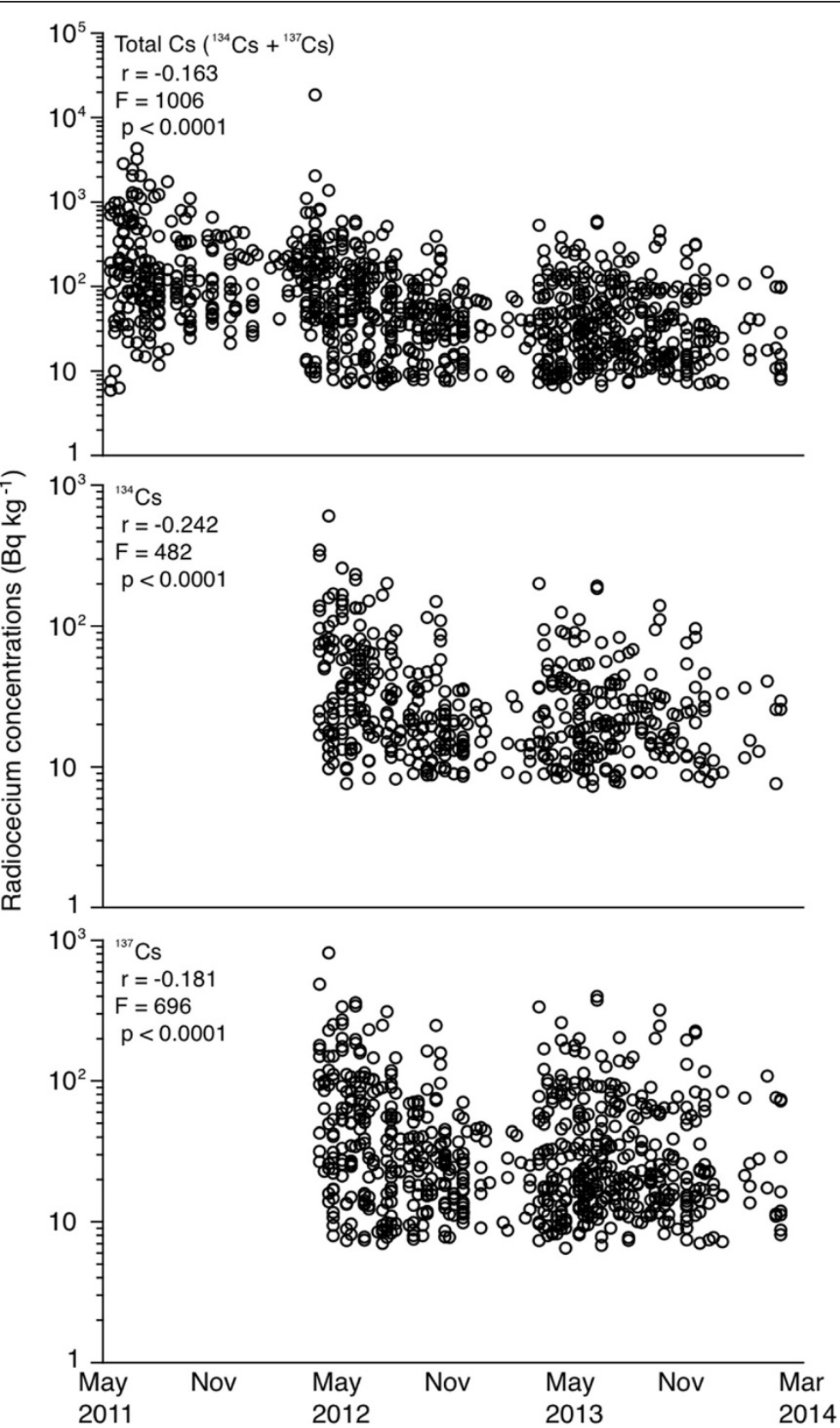

Figure 2 Variations in the total radiocesium concentrations (top) between May 2011 and March 2014 , the ${ }^{134} \mathrm{Cs}$ (middle) and ${ }^{137} \mathrm{Cs}$ (bottom) concentrations between April 2012 and February 2014. The total $C s,{ }^{134} \mathrm{Cs}$ and ${ }^{137} \mathrm{Cs}$ concentrations decreased significantly during the three years after the F1NPP accident; however, high concentrations exceeded the $100 \mathrm{~Bq} \mathrm{~kg}^{-1}$ interim limit for radiocesium in Japan were detected. All of the radiocesium data for the salmonids were from the information published by the Fisheries Agency of the Japanese Government (2014a) between May 2011 and March 2014.

in the Fukushima region, which was followed by the Koriyama and Aizu regions $(\mathrm{F}=37-41$ and $\mathrm{p}<0.05$ 0.005); no significant differences were found between the Fukushima region and the Iwaki region $(F=47$ and $\mathrm{p}>0.05$ ) (Figure 4). There were no significant differences found between other combinations ( $F=37-64$ and $\mathrm{p}>0.05$ ) (Figure 4).
The total cesium concentrations between April 2012 and March 2013 ranged from nd to $65 \mathrm{~Bq} \mathrm{~kg}^{-1}$ (19.4 \pm $24.5 \mathrm{~Bq} \mathrm{~kg}^{-1}$ ) in Iwaki region, nd to $1400 \mathrm{~Bq} \mathrm{~kg}^{-1}(261 \pm$ $\left.242 \mathrm{~Bq} \mathrm{~kg}^{-1}\right)$ in the Fukushima region, nd to $250 \mathrm{~Bq} \mathrm{~kg}^{-1}$ $\left(55.9 \pm 63.9 \mathrm{~Bq} \mathrm{~kg}^{-1}\right)$ in the Koriyama region and nd to $420 \mathrm{~Bq} \mathrm{~kg}{ }^{-1}\left(37.3 \pm 54.2 \mathrm{~Bq} \mathrm{~kg}{ }^{-1}\right)$ in the Aizu region (Figure 4). The ${ }^{134} \mathrm{Cs}$ and ${ }^{137} \mathrm{Cs}$ concentrations in these 
Table 2 Radiocecium concentrations (exceeding the detection limit) in freshwater fishes examined between May 2011 and March 2014 in the present study

\begin{tabular}{|c|c|c|c|c|c|c|c|c|c|}
\hline \multirow[t]{2}{*}{ Species } & \multicolumn{3}{|c|}{$\begin{array}{l}\text { Mean } \pm \text { SD }(\mathrm{Bq} / \mathrm{kg}) \text { between } \\
\text { May } 2011 \text { and March } 2012 \\
\text { (minimum-maximum }(\mathrm{Bq} / \mathrm{kg}) \text { ) }\end{array}$} & \multicolumn{3}{|c|}{$\begin{array}{l}\text { Mean } \pm \text { SD }(\mathrm{Bq} / \mathrm{kg}) \text { between } \\
\text { April } 2012 \text { and March } 2013 \\
\text { (minimum-maximum }(\mathrm{Bq} / \mathrm{kg}) \text { ) }\end{array}$} & \multicolumn{3}{|c|}{$\begin{array}{l}\text { Mean } \pm \text { SD }(\mathrm{Bq} / \mathrm{kg}) \text { between } \\
\text { April } 2013 \text { and March } 2014 \\
\text { (minimum-maximum }(\mathrm{Bq} / \mathrm{kg}) \text { ) }\end{array}$} \\
\hline & Total Cs* & ${ }^{134} \mathrm{Cs}$ & ${ }^{137} \mathrm{Cs}$ & Total Cs* & ${ }^{134} \mathrm{Cs}$ & ${ }^{137} \mathrm{Cs}$ & Total Cs* & ${ }^{134} \mathrm{Cs}$ & ${ }^{137} \mathrm{Cs}$ \\
\hline Plecoglossus altivelis & $530 \pm 822$ & $\mathrm{n} / \mathrm{a}$ & $\mathrm{n} / \mathrm{a}$ & $60.9 \pm 61.0$ & $29.1 \pm 25.2$ & $37.9 \pm 35.5$ & $50.9 \pm 42.3$ & $22.8 \pm 12.4$ & $36.6 \pm 28.4$ \\
\hline (ayu) & $7.7-4400$ & & & $8.5-280$ & $8.4-116$ & $7.58-164$ & $7.9-200$ & $11.8-61.3$ & $7.9-140$ \\
\hline Salvelinus leucomaenis & $154 \pm 145$ & $\mathrm{n} / \mathrm{a}$ & $\mathrm{n} / \mathrm{a}$ & $94.2 \pm 127$ & $46.3 \pm 54.2$ & $59.3 \pm 76.1$ & $49.6 \pm 75.1$ & $26.2 \pm 29.6$ & $36.1 \pm 50.4$ \\
\hline (white-spotted char) & $6.4-590$ & & & $7.4-840$ & $7.7-350$ & $7.4-490$ & $6.5-600$ & 7.4-194 & $6.5-403$ \\
\hline Tribolodon hakonensis & $207 \pm 405$ & $\mathrm{n} / \mathrm{a}$ & $\mathrm{n} / \mathrm{a}$ & $75.4 \pm 103$ & $45.9 \pm 46.5$ & $48.3 \pm 61.0$ & $48.1 \pm 78.1$ & $32.2 \pm 33.3$ & $34.8 \pm 51.5$ \\
\hline (Japanese dace) & $11-2500$ & & & $7.8-420$ & $8.8-171$ & $7.8-253$ & $7.1-390$ & $7.9-126$ & $7.1-261$ \\
\hline Anguilla japonica & $129 \pm 21$ & $\mathrm{n} / \mathrm{a}$ & $\mathrm{n} / \mathrm{a}$ & $191 \pm 179$ & $74.7 \pm 69.8$ & $114 \pm 106$ & & & \\
\hline (Japanese eel) & $114-143$ & & & $44-390$ & $16.4-152$ & $27.5-82.3$ & 58-110 & $21.4-34.9$ & $36.2-78.6$ \\
\hline Carassius langsdorfii & $86 \pm 40$ & $\mathrm{n} / \mathrm{a}$ & $\mathrm{n} / \mathrm{a}$ & $94.7 \pm 91.7$ & $37.0 \pm 38.6$ & $57.3 \pm 52.2$ & $94.5 \pm 91.0$ & $34.8 \pm 30.1$ & $64.3 \pm 61.7$ \\
\hline (Japanese silver crucian carp) & $43-188$ & & & $24-310$ & $8.6-128$ & $11.2-177$ & $8.9-310$ & $8.9-112$ & $8.9-205$ \\
\hline Carassius cuvieri & $29 \pm 202$ & $\mathrm{n} / \mathrm{a}$ & $\mathrm{n} / \mathrm{a}$ & 170 & 64.1 & 103 & & & \\
\hline (Japanese white crucian carp) & $88-98$ & & & & & & $67-120$ & 20.6-38.6 & 45.9-85.3 \\
\hline Cyprinus carpio & $80 \pm 46$ & $\mathrm{n} / \mathrm{a}$ & $\mathrm{n} / \mathrm{a}$ & $66.9 \pm 66.7$ & $31.8 \pm 27.8$ & $40.0 \pm 39.1$ & $49.3 \pm 36.2$ & $22.0 \pm 10.3$ & $35.8 \pm 24.1$ \\
\hline (common carp) & $15-155$ & & & $13-280$ & $9.4-114$ & $9.9-166$ & $9.6-110$ & 7.8-37.7 & $9.6-76.6$ \\
\hline Micropterus dolomieu & $118 \pm 130$ & $\mathrm{n} / \mathrm{a}$ & $\mathrm{n} / \mathrm{a}$ & $\mathrm{n} / \mathrm{a}$ & $\mathrm{n} / \mathrm{a}$ & $\mathrm{n} / \mathrm{a}$ & $\mathrm{n} / \mathrm{a}$ & $\mathrm{n} / \mathrm{a}$ & $\mathrm{n} / \mathrm{a}$ \\
\hline (smallmouth bass) & $10.2-330$ & & & & & & & & \\
\hline Misgurnus anguillicaudatu & $49.7 \pm 25.6$ & $\mathrm{n} / \mathrm{a}$ & $\mathrm{n} / \mathrm{a}$ & 9.7 & nd & nd & nd & nd & nd \\
\hline (weather loach) & $21.6-83$ & & & & & & & & \\
\hline Hemibarbus barbus & & $\mathrm{n} / \mathrm{a}$ & $\mathrm{n} / \mathrm{a}$ & $\mathrm{n} / \mathrm{a}$ & $\mathrm{n} / \mathrm{a}$ & $\mathrm{n} / \mathrm{a}$ & $\mathrm{n} / \mathrm{a}$ & $\mathrm{n} / \mathrm{a}$ & $\mathrm{n} / \mathrm{a}$ \\
\hline (barbel steed) & $83-110$ & & & & & & & & \\
\hline Oncorhynchus mykiss & nd & $n / a$ & $\mathrm{n} / \mathrm{a}$ & nd & nd & nd & $\mathrm{n} / \mathrm{a}$ & $\mathrm{n} / \mathrm{a}$ & $\mathrm{n} / \mathrm{a}$ \\
\hline \multicolumn{10}{|l|}{ (rainbow trout) } \\
\hline Oncorhynchus nerka & $106 \pm 42.1$ & $\mathrm{n} / \mathrm{a}$ & $\mathrm{n} / \mathrm{a}$ & $136 \pm 32.2$ & $51.1 \pm 15.7$ & $85.5 \pm 18.7$ & $112 \pm 27.6$ & $34.1 \pm 10.8$ & $77.6 \pm 17.7$ \\
\hline (sockeye salmon) & $36-158$ & & & $89-200$ & $34.2-82$ & $55.2-120$ & $81-170$ & $21.8-55.5$ & $54.4-110$ \\
\hline Oncorhynchus masou & $586 \pm 2360$ & $\mathrm{n} / \mathrm{a}$ & $\mathrm{n} / \mathrm{a}$ & $116 \pm 199$ & $59.2 \pm 92.0$ & $71 \pm 117$ & $70 \pm 101$ & $35.9 \pm 36.1$ & $49.4 \pm 68.4$ \\
\hline (masu salmon) & $6-18700$ & & & $7.1-1430$ & $8.9-610$ & $7.1-820$ & $6.8-570$ & $7.7-187$ & $6.8-378$ \\
\hline Hypomesus nipponensis & $307 \pm 167$ & $\mathrm{n} / \mathrm{a}$ & $\mathrm{n} / \mathrm{a}$ & $48.2 \pm 18.2$ & $18.7 \pm 6.1$ & $30.2 \pm 12.2$ & $32.7 \pm 19.2$ & $16.7 \pm 6.2$ & $23.6 \pm 10.0$ \\
\hline (pond smelt) & $27-870$ & & & $9.9-76$ & $8.5-31.8$ & $9.9-46.9$ & $14-76$ & $11.7-28.6$ & $14.4-47.6$ \\
\hline
\end{tabular}

*Total $\mathrm{Cs}={ }^{134} \mathrm{Cs}+{ }^{137} \mathrm{Cs}$.

Total Cs was available between May 2011 and March 2014

${ }^{134} \mathrm{Cs}+{ }^{137} \mathrm{Cs}$ were available between April 2012 and March 2014.

n/a: not applicable.

nd: All samples were below detection limit.

regions during the same period were nd to $25.5 \mathrm{~Bq} \mathrm{~kg}^{-1}$ $\left(8.19 \pm 10.8 \mathrm{~Bq} \mathrm{~kg}{ }^{-1}\right)$ and nd to $39.3 \mathrm{~Bq} \mathrm{~kg}^{-1}(11.1 \pm$ $\left.14.8 \mathrm{~Bq} \mathrm{~kg}^{-1}\right)$, nd to $610 \mathrm{~Bq} \mathrm{~kg}^{-1}\left(104 \pm 102 \mathrm{~Bq} \mathrm{~kg}^{-1}\right)$ and nd to $820 \mathrm{~Bq} \mathrm{~kg}^{-1}\left(156 \pm 143 \mathrm{~Bq} \mathrm{~kg}^{-1}\right)$, nd to $100 \mathrm{~Bq}$ $\left.\mathrm{kg}^{-1}(21.4 \pm 26.3 \mathrm{~Bq} \mathrm{~kg})^{-1}\right)$ and nd to $150 \mathrm{~Bq} \mathrm{~kg}^{-1}(34.4 \pm$ $\left.37.6 \mathrm{~Bq} \mathrm{~kg}{ }^{-1}\right)$ and nd to $171 \mathrm{~Bq} \mathrm{~kg}^{-1}(13.8 \pm 22.1 \mathrm{~Bq}$ $\left.\mathrm{kg}^{-1}\right)$ and nd to $253 \mathrm{~Bq} \mathrm{~kg}{ }^{-1}\left(23.5 \pm 32.5 \mathrm{~Bq} \mathrm{~kg}^{-1}\right)$, respectively (Figure 4). Significantly higher concentrations of total cesium, ${ }^{134} \mathrm{Cs}$ and ${ }^{137} \mathrm{Cs}$ were found in the Fukushima region compared with the other regions
( $\mathrm{F}=57$ to 63 and $\mathrm{p}<0.0001$ ), while no significant differences were found between the other regions $(\mathrm{F}=6-82$ and $\mathrm{p}>0.05$ ) (Figure 4).

The total Cs, ${ }^{34} \mathrm{Cs}$ and ${ }^{137} \mathrm{Cs}$ concentrations between April 2013 and March 2014 ranged from nd to $82 \mathrm{~Bq} \mathrm{~kg}^{-1}$ $\left(13.3 \pm 30.6 \mathrm{~Bq} \mathrm{~kg}^{-1}\right)$, nd to $26.6 \mathrm{~Bq} \mathrm{~kg}^{-1}\left(3.8 \pm 10.1 \mathrm{~Bq} \mathrm{~kg}^{-1}\right)$ and nd to $55.5 \mathrm{~Bq} \mathrm{~kg}^{-1}\left(9.4 \pm 20.7 \mathrm{~Bq} \mathrm{~kg}^{-1}\right)$ in the Iwaki region, from nd to $600 \mathrm{~Bq} \mathrm{~kg}^{-1}\left(126 \pm 126 \mathrm{~Bq} \mathrm{~kg}^{-1}\right)$, nd to $194 \mathrm{~Bq} \mathrm{~kg}{ }^{-1}\left(38.7 \pm 40.9 \mathrm{~Bq} \mathrm{~kg}^{-1}\right)$ and nd to $403 \mathrm{~Bq} \mathrm{~kg}^{-1}$ $\left(87.1 \pm 85.5 \mathrm{~Bq} \mathrm{~kg}^{-1}\right)$ in the Fukushima region, from nd to 


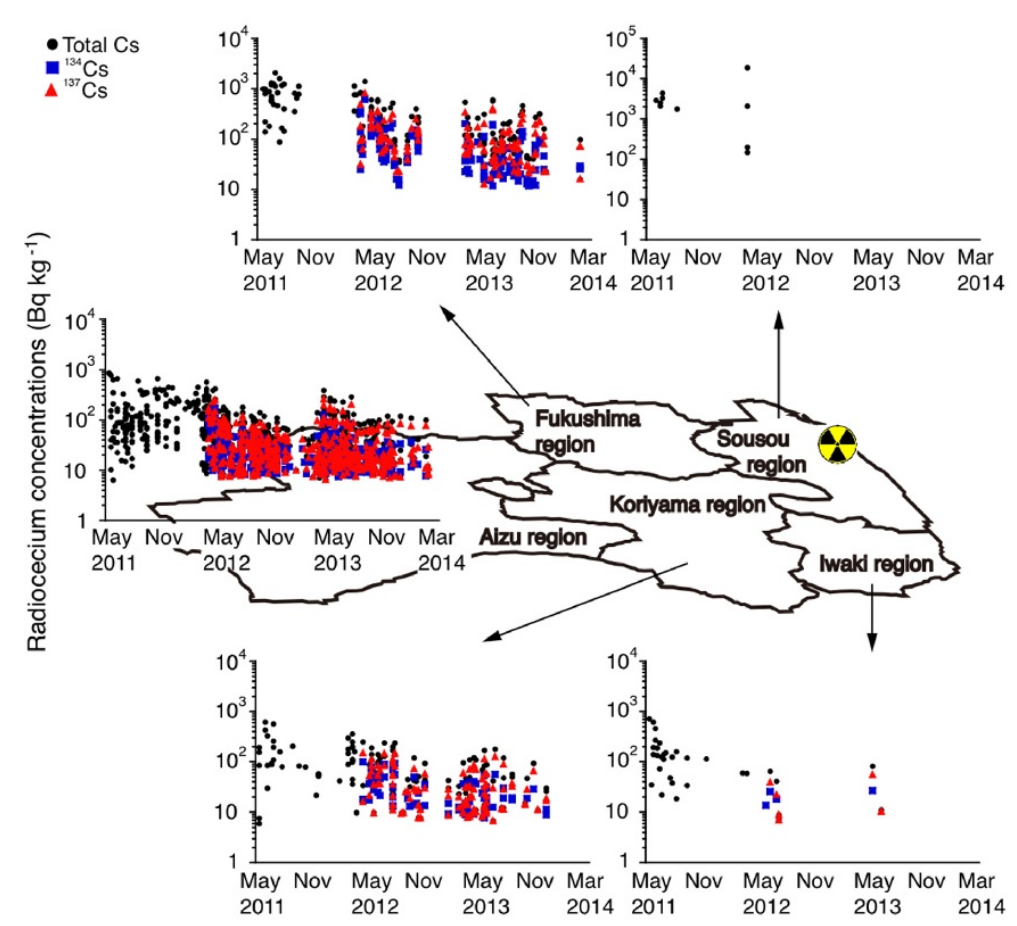

Figure 3 Temporal and spatial variations in the radiocesium concentrations for three years in five regions in Fukushima prefecture. Among the five regions in Fukushima Prefecture, almost all sites exhibited a gradual decrease in each radiocesium isotope concentration during the three-year period.

$180 \mathrm{~Bq} \mathrm{~kg}^{-1}\left(25.8 \pm 40.1 \mathrm{~Bq} \mathrm{~kg}^{-1}\right)$, nd to $56.3 \mathrm{~Bq} \mathrm{~kg}^{-1}(7.4 \pm$ 13.4 $\left.\mathrm{Bq} \mathrm{kg}^{-1}\right)$ and nd to $127 \mathrm{~Bq} \mathrm{~kg}^{-1}\left(18.3 \pm 27.1 \mathrm{~Bq} \mathrm{~kg}^{-1}\right)$ in the Koriyama region and from nd to $390 \mathrm{~Bq} \mathrm{~kg}^{-1}(28.1 \pm$ $\left.48.7 \mathrm{~Bq} \mathrm{~kg}^{-1}\right)$, nd to $126 \mathrm{~Bq} \mathrm{~kg}^{-1}\left(7.7 \pm 16.2 \mathrm{~Bq} \mathrm{~kg}^{-1}\right)$ and nd to $261 \mathrm{~Bq} \mathrm{~kg}^{-1}\left(20.3 \pm 32.9 \mathrm{~Bq} \mathrm{~kg}^{-1}\right)$ in the Aizu region (Figure 4). Significantly higher total Cs, ${ }^{134} \mathrm{Cs}$ and ${ }^{137} \mathrm{Cs}$ concentrations were found in the Fukushima compared to the other regions $(\mathrm{F}=35$ to 74 and $\mathrm{p}<0.0001)$, while no significant differences were found between the other regions $(\mathrm{F}=6-143$ and $\mathrm{p}>0.05)$ (Figure 4).

In the Iwaki, Fukushima, Koriyama and Aizu regions, the detectable rate of each radiocesium isotope decreased during the three years except for the Fukushima region (Table 3). Although a limited number of sample were examined for the Iwaki region between April 2012 and March 2014, the detectable rate for each radiocesium isotope decreased by less than $30 \%$ during the third year, which was less than the $80 \%$ reduction that was observed in the total cesium detection rate during the first year (Table 3). In the Koriyama and Aizu regions, the detectable rates for ${ }^{134} \mathrm{Cs}$ decreased by $30 \%$ in the third year; the second year exhibited a decrease that exceeded 50\% (Table 3). Regarding the total cesium and ${ }^{137} \mathrm{Cs}$ in these regions, the detectable rates also decreased during years two and three (Table 3). However, such tendencies were not found in the Fukushima region. The detectable rates for the total cesium and ${ }^{137} \mathrm{Cs}$ in the Fukushima region were constant more than $95 \%$ of the time 3 years of the F1NPP accident. Although the detectable rate for ${ }^{134} \mathrm{Cs}$ decreased slightly between the second year and third year, the detectable rates in each year (98\% in the second year and $86 \%$ in third year) clearly exceeded those for the other regions (Table 3). These results suggest that radiocesium inputs continue in the Fukushima region compared with the other regions in Fukushima prefecture.

\section{Accumulation patterns of radiocesium in freshwater fish species}

In the present study, the highest Cs concentration was found in masu salmon (18700 Bq kg$\left.{ }^{-1}\right)$. The second highest concentration was found in ayu (2900-4400 Bq kg-1), while the third highest concentration was found in Japanese dace $\left.(2500 \mathrm{~Bq} \mathrm{~kg})^{-1}\right)$. All of these fish were collected in the Sousou region between May 2011 and March 2012 (Table 2 and Figure 5). In this study, eight of the 14 freshwater fish species could be examined throughout the three-year period because a sufficient number of samples was available (Table 2 and Figure 5). Although the most recent data did not exhibit concentrations exceeding $1000 \mathrm{~Bq} \mathrm{~kg}{ }^{-1}$ or $10000 \mathrm{~Bq} \mathrm{~kg}{ }^{-1}$ in freshwater species, concentrations exceeding $100 \mathrm{~Bq} \mathrm{~kg}$, which is the safety threshold for the total Cs that was introduced in April 2012 in Japan, were detected (Table 2 and Figure 5). 


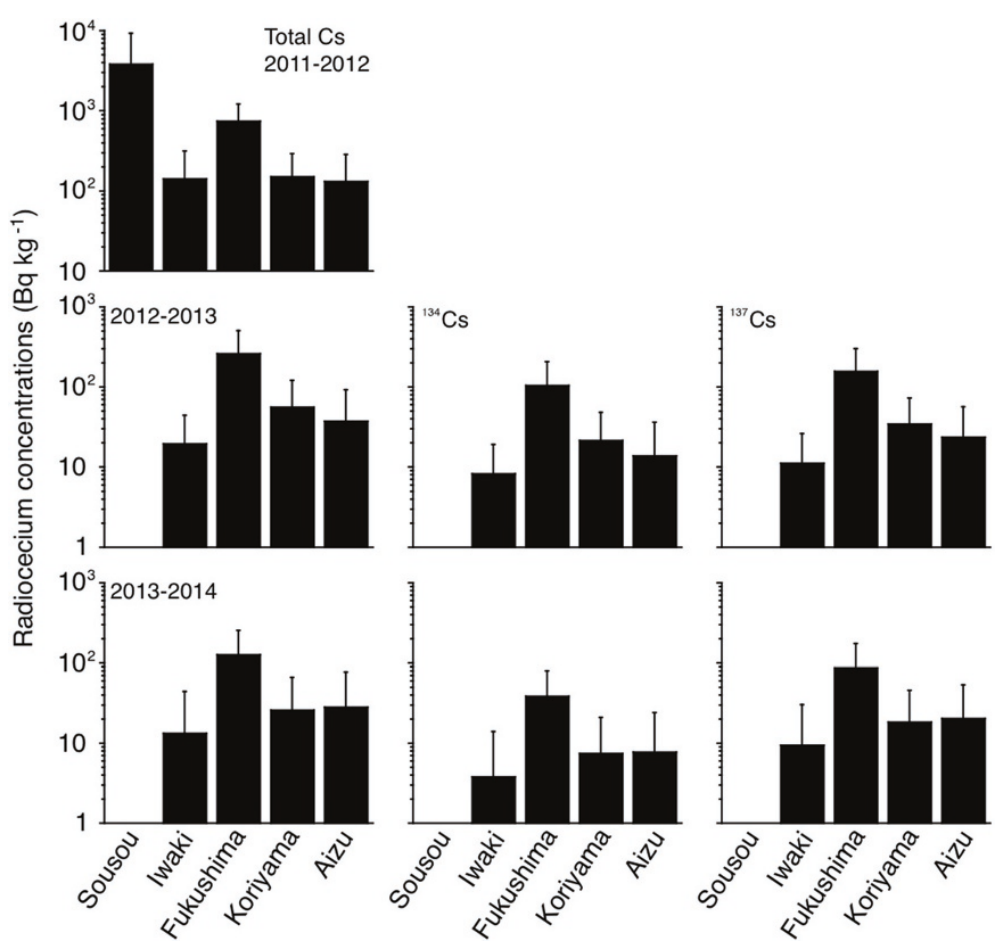

Figure 4 Differences in radiocesium accumulations among the five regions between May 2011 and March 2014, i.e., after the F1NPP accident. Between May 2011 and March 2012, the highest total Cs concentration was found in the Sousou region. The second highest concentration was found in the Fukushima region, which was followed by the Koriyama and Aizu regions. Significantly higher total Cs, ${ }^{134} \mathrm{Cs}$ and ${ }^{137} \mathrm{Cs}$ concentrations were found in the Fukushima region compared to the other regions between April 2012 and March 2013 and between April 2013 and March 2014.

Negative correlations between each radiocesium (i.e., total Cs, ${ }^{134} \mathrm{Cs},{ }^{137} \mathrm{Cs}$ ) concentration and the elapsed time were found in ayu $(\mathrm{F}=38-120$ and $\mathrm{p}<0.0001)$, white-spotted char $(\mathrm{F}=156-282$ and $\mathrm{p}<0.0001)$ and Japanese dace $(\mathrm{F}=48-136$ and $\mathrm{p}<0.05-0.0005)$ (Figure 5). Negative relationships were found between the total Cs and ${ }^{134} \mathrm{Cs}$ concentrations and the elapsed time $(\mathrm{F}=25$ 45 and $\mathrm{p}<0.05$ ), while no correlation was found for the ${ }^{137} \mathrm{Cs}$ concentration $(\mathrm{F}=34$ and $\mathrm{p}>0.1)$ in common carp (Figure 5). In sockeye salmon, a negative relationship was found between the ${ }^{134} \mathrm{Cs}$ concentrations and the elapsed time $(\mathrm{F}=26$ and $\mathrm{p}<0.0001)$, while no correlations were found for the total $\mathrm{Cs}$ and ${ }^{137} \mathrm{Cs}$ concentrations $(\mathrm{F}=26-32$ and $\mathrm{p}>0.1-0.5)$. Moreover, the ${ }^{134} \mathrm{Cs}$ and ${ }^{137} \mathrm{Cs}$ concentrations decreased significantly during the three years $(F=118-177$ and $\mathrm{p}<0.05)$, while no relationship was found for the total Cs concentration ( $\mathrm{F}=$ 240 and $\mathrm{p}>0.05)$ in masu salmon. Furthermore, nearly the same negative relationship was found between the total $\mathrm{Cs}$ and ${ }^{137} \mathrm{Cs}$ concentrations and the elapsed time ( $\mathrm{F}=36-75$ and $\mathrm{p}<0.05-0.0001)$, while no correlation was found for the ${ }^{134} \mathrm{Cs}$ concentration $(\mathrm{F}=30$ and $\mathrm{p}>0.1)$ in Japanese smelt. No negative relationships were found between the total Cs, ${ }^{134} \mathrm{Cs}$ and ${ }^{137} \mathrm{Cs}$ concentrations and the elapsed time in Japanese silver crucian carp $(F=26-$
44 and $\mathrm{p}>0.1-0.5)$. Although each radiocesium concentration decreased significantly in most of the studied freshwater fish species, the tendencies varied among the species (Figure 5).

\section{Discussion}

The present study showed that radiocesium accumulation gradually decreased during the three years after the F1NPP accident in Fukushima prefecture. However, concentrations exceeding $100 \mathrm{~Bq} \mathrm{~kg}^{-1}$, which is the interim limit for radiocesium level in Japan, were detected in several fish species (Figure 2). Radioactive accumulation in freshwater fish occurs when the fish retain contaminated materials from freshwater environments. The results of this study also suggest that radiocesium accumulation in terrestrial environments in the Fukushima regions decreased gradually after the accident. However, brown trout in a Norwegian lake that was contaminated by radiocesium fallout from the Chernobyl accident still contain radiocesium accumulations more than 20 years after the accident; these concentrations are thought to be no longer decreasing (Brittain and Gjerseth 2010). This phenomenon might be due to the continual input of radiocesium substances from the catchment and remobilization in the local terrestrial environment. 
Table 3 Radiocesium data information in five regions in Fukushima prefecture examined between May 2011 and March 2014 in the present study

\begin{tabular}{|c|c|c|c|c|c|c|c|c|c|c|c|c|}
\hline \multirow[t]{2}{*}{ Region } & \multirow[t]{2}{*}{$\begin{array}{l}\text { Number of analysed } \\
\text { betweeen May } 2011 \\
\text { and March } 2012\end{array}$} & \multicolumn{3}{|c|}{$\begin{array}{l}\text { Number of data above } \\
\text { detection limit betweeen May } \\
2011 \text { and March } 2012 \text { (Ratio of } \\
\text { detectable (\%)) }\end{array}$} & \multirow[t]{2}{*}{$\begin{array}{l}\text { Number of analysed } \\
\text { betweeen April } 2012 \\
\text { and March } 2013\end{array}$} & \multicolumn{3}{|c|}{$\begin{array}{l}\text { Number of data above } \\
\text { detection limit betweeen April } \\
2012 \text { and March } 2013 \text { (Ratio of } \\
\text { detectable (\%)) }\end{array}$} & \multirow[t]{2}{*}{$\begin{array}{l}\text { Number of analysed } \\
\text { betweeen April } 2013 \\
\text { and March } 2014\end{array}$} & \multicolumn{3}{|c|}{$\begin{array}{l}\text { Number of data above } \\
\text { detection limit betweeen April } \\
2013 \text { and March } 2014 \text { (Ratio of } \\
\text { detectable (\%)) }\end{array}$} \\
\hline & & Total Cs* & ${ }^{134} \mathrm{Cs}$ & ${ }^{137} \mathrm{Cs}$ & & Total Cs* & ${ }^{134} \mathrm{Cs}$ & ${ }^{137} \mathrm{Cs}$ & & Total Cs* & ${ }^{134} \mathrm{Cs}$ & ${ }^{137} \mathrm{Cs}$ \\
\hline \multirow[t]{2}{*}{ Sousou region } & 10 & 10 & $\mathrm{n} / \mathrm{a}$ & $\mathrm{n} / \mathrm{a}$ & $n / a$ & $n / a$ & $\mathrm{n} / \mathrm{a}$ & $\mathrm{n} / \mathrm{a}$ & $\mathrm{n} / \mathrm{a}$ & $\mathrm{n} / \mathrm{a}$ & $\mathrm{n} / \mathrm{a}$ & $n / a$ \\
\hline & & $(100)$ & & & & & & & & & & \\
\hline \multirow[t]{2}{*}{ Iwaki region } & 31 & 26 & $\mathrm{n} / \mathrm{a}$ & $\mathrm{n} / \mathrm{a}$ & 9 & 7 & 3 & 4 & 7 & 2 & 1 & 2 \\
\hline & & (83.9) & & & & (77.8) & (33.3) & $(44.4)$ & & (28.6) & (14.3) & (28.6) \\
\hline \multirow[t]{2}{*}{ Fukushima region } & 37 & 37 & $\mathrm{n} / \mathrm{a}$ & $\mathrm{n} / \mathrm{a}$ & 58 & 57 & 57 & 57 & 65 & 63 & 56 & 63 \\
\hline & & $(100)$ & & & & (98.3) & $(98.3)$ & $(98.3)$ & & $(96.9)$ & $(86.1)$ & (96.9) \\
\hline \multirow[t]{2}{*}{ Koriyama region } & 43 & 42 & $\mathrm{n} / \mathrm{a}$ & $\mathrm{n} / \mathrm{a}$ & 70 & 57 & 43 & 57 & 83 & 48 & 26 & 48 \\
\hline & & $(97.7)$ & & & & (81.4) & $(61.4)$ & (81.4) & & $(57.8)$ & (31.3) & (57.8) \\
\hline \multirow[t]{2}{*}{ Aizu region } & 210 & 188 & $\mathrm{n} / \mathrm{a}$ & $\mathrm{n} / \mathrm{a}$ & 541 & 369 & 278 & 364 & 358 & 230 & 117 & 228 \\
\hline & & (89.5) & & & & (68.2) & (51.3) & (67.3) & & $(64.2)$ & (32.7) & (63.7) \\
\hline
\end{tabular}

${ }^{*}$ Total $\mathrm{Cs}={ }^{134} \mathrm{Cs}+{ }^{137} \mathrm{Cs}$.

Total Cs was available between May 2011 and March 2014

${ }^{134} \mathrm{Cs}+{ }^{137} \mathrm{Cs}$ were available between April 2012 and March 2014

n/a: not applicable. 


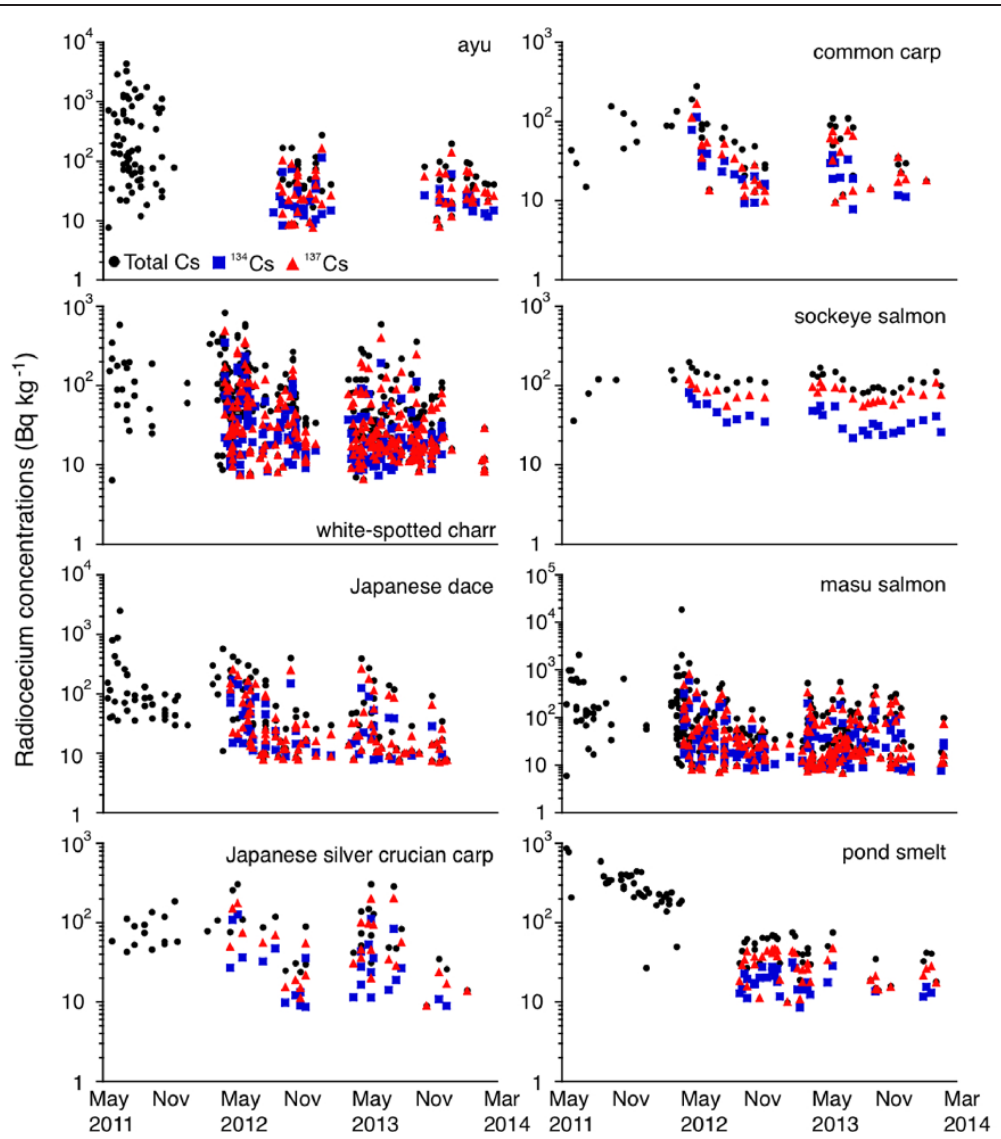

Figure 5 Accumulation patterns of radiocesium in freshwater fish species for three years. The highest concentration was found in masu salmon (18700 Bq kg-1). The second highest concentration was found in ayu (2900-4400 Bq kg ${ }^{-1}$ ), while the third highest concentration was found in Japanese dace $\left(2500 \mathrm{~Bq} \mathrm{~kg}^{-1}\right)$. All of the fish were collected in the Sousou region between May 2011 and March 2012. Although each radiocesium isotope concentration decreased significantly in most of the freshwater fish species, the tendencies varied among the species.

Therefore, continuous long-term monitoring of radioactive accumulation in fish is needed to understand the fate and effects in terrestrial environments and to evaluate the aftermath of the F1NPP accident. Because fish are major structural and functional components in freshwater ecosystems, radioactive contamination of fish should be avoided because they are consumed by terrestrial animals and human. Sporadically detected accumulations exceeding the interim limit for foods in the Fukushima regions were detected even three years after the F1NPP accident. The Japanese interim limit for imported foods was $370 \mathrm{~Bq} \mathrm{~kg}{ }^{-1}$ for the total Cs concentration after the Chernobyl nuclear accident in 1986. The interim limit after the F1NPP accident was initially set at $500 \mathrm{~Bq} \mathrm{~kg}^{-1}$, however stricter limit of $100 \mathrm{~Bq} \mathrm{~kg}^{-1}$ was introduced in April 2012. A tissue analysis indicated that $75 \%$ of the total ${ }^{137} \mathrm{Cs}$ accumulated in the flesh of the examined fish, i.e. the edible parts of the fish (Malek et al. 2004). This result indicated that most of the consumed ${ }^{137} \mathrm{Cs}$ by fish was deposited in soft tissue. Therefore, as long as radiocesium that exceed the interim limit are detected in fish, commercial fisheries and consumption of fish from these regions should be prohibited in the Fukushima regions.

Radiocesium accumulation patterns in fish in Fukushima prefecture differed among the studied regions. The highest accumulation of total Cs was found in the Sousou region, which is where the F1NPP site is located; the accumulations tended to decrease as a function of the distance from the F1NPP site (Figure 4). However, the radiocesium accumulations in the Fukushima region were significantly higher than those in the Iwaki and Koriyama regions despite these regions being located adjacent to the Sousou region (Figure 4). The spatial accumulation patterns of radiocesium found in the present study represent welldocumented natural radiocesium levels. The deposition of radiocesium on the land surrounding the F1NPP site was evident due to the higher levels that were detected in northwest of the FINPP site (Figure 1B). Date city and Kawamata town are associated with the Fukushima region; higher total $\mathrm{Cs}$ concentrations (from $10^{6}$ to $30^{6} \mathrm{~Bq} \mathrm{~m}^{-3}$ ) were detected in these areas compared to the surrounding locations in April 2011; the concentrations 
in the Iwaki and Koriyama regions were less than $30^{5}$ $60^{5} \mathrm{~Bq} \mathrm{~m}^{-3}$ (Figure 1B). The deposition patterns of rediocesium might correspond to the atmospheric circulation; therefore environmental radiocesium levels in the Fukushima region were higher than in the Iwaki and Koriyama regions, which caused the higher accumulation of radiocesium in fish in the Fukushima region. The detectable rate of each radiocesium isotope concentration was much higher in the Fukushima region, i.e., 97-100\% for the total Cs and ${ }^{137} \mathrm{Cs}$ concentration and $86-98 \%$ for the ${ }^{134} \mathrm{Cs}$ concentration throughout the three-year period between May 2011 and March 2014. However, the detectable rates in the Iwaki and Koriyama regions decreased to $14-29 \%$ and $31-58 \%$, respectively (Table 3). These results suggest that radionuclides remain in the natural environment with less convergence. Moreover, there is a continual input of radiocesium substances from the F1NPP site into the local terrestrial environment.

Radiocesium accumulations in freshwater fish species examined in the present study might represent the spatial accumulations of these radionuclides. Arai (2014) found that salmon migration patterns revealed the temporal and spatial variations in radiocesium concentrations in terrestrial and oceanic environments. In the present study, three salmon species, i.e., white-spotted char, sockeye salmon and masu salmon, were examined. The accumulation trends of radiocesium during the studied three-year period in these salmon species were similar to those found for all freshwater fish species (Figures 2 and 5). Because these salmon species, especially the white-spotted char and masu salmon are common species and are distributed over a broader region in Japan and other East Asian countries, these salmon species may be good indicators for tracing the environmental radiocesium levels after the F1NPP accident.

Although the higher levels of radiocesium in freshwater fish are caused by the serious contamination in the terrestrial environments surrounding Fukushima prefecture after the F1NPP accident, freshwater fish exhibit ${ }^{137} \mathrm{Cs}$ concentrations that are approximately 100 times higher than those of marine fishes due to the presence of potassium, which is less abundant in freshwater. This difference results in the accelerated uptake of cesium by freshwater organisms (Harte et al. 1991). Thus, the differences in the physiological mechanisms, especially the ionic uptake and elimination of the related osmoregulation, might also accelerate ${ }^{137} \mathrm{Cs}$ accumulation in freshwater fish. The F1NPP accident released large amounts of radioactive substances into the environment and contaminated the soil of the Tohoku and the Kanto (East) districts in Japan. The radiocesium concentrations in the water, soil and biota in the terrestrial environment are much higher than those of the coastal and marine environments (Yasunari et al. 2011; Buesseler et al. 2012; Arai 2014). The natural habitats of freshwater fish vary among species. Although fish reside in streams, ponds and lakes, several species have restricted home ranges. In the present study, the accumulation trends of radiocesium as a function of the elapsed times were different among the studied species (Figure 5). Many studies have analysed the accumulation and loss of radiocesium in freshwater fishes (Meili 1991; Ugedal et al. 1992; Forseth et al. 1992; Morgan et al. 1993; Rowan and Rasumussen 1995; Peters et al. 1999; Malek et al. 2004). There are several ways in which fish can take up radionuclides: (1) uptake through a contaminated diet in which the food is contaminated due to contact with contaminated water or by food chain intake (2) absorption through the skin, and (3) absorption through the gills (Malek et al. 2004). The present study suggests that freshwater fish may uptake radiocesium primarly from contaminated diets; however, the contamination levels vary according to the environmental radiocesium levels.

In freshwater ecosystems, the initial dynamic phase of ${ }^{137} \mathrm{Cs}$ contamination and equilibration after a fallout lasts up to five years and appears to be largely determined by biological processes (Bergan 1995). Thereafter, ${ }^{137} \mathrm{Cs}$ activities in fish approach a steady state, with a slow decrease that is likely controlled by continuous secondary inputs of ${ }^{137} \mathrm{Cs}$ into freshwater environments such as streams, lakes and ponds and their food webs (Bergan 1995). The most likely sources are the loss of ${ }^{137} \mathrm{Cs}$ from land to water and the recycling of ${ }^{137} \mathrm{Cs}$ from sediments. While fluxes and abiotic concentrations of ${ }^{137} \mathrm{Cs}$ decrease, the bioavailability of ${ }^{137} \mathrm{Cs}$ in freshwater ecosystems continually decreases (Bergan 1995). However, in regard to the F1NPP accident, only three years have passed. Therefore the initial dynamic phase of contamination and equilibration may be still continuing and unstable. However, the present study has suggested that the accumulation of radiocesium has gradually decreased in freshwater fish in the Fukushima regions. Monitoring the long-term behaviour of radionuclides in the environment is an important issue for estimating possible radiological consequences and associated risks. This monitoring is also important for evaluating the potential use of contaminated areas and the possible effectiveness of remediation activities. Further continuous monitoring is indispensable for understanding radionuclide behaviour in freshwater ecosystems and human health after the F1NPP accident.

\section{Competing interests \\ The author declares that he has no competing interests.}

Received: 23 July 2014 Accepted: 25 August 2014

Published: 28 August 2014

\section{References}

Arai T (2014) Salmon migration patterns revealed the temporal and spatial fluctuations of the radiocesium levels in terrestrial and ocean environments. PLoS One 9:e100779

Baudin J (2000) Dietary uptake, retention and tissue distribution of ${ }^{54} \mathrm{Mn},{ }^{60} \mathrm{Co}$ and ${ }^{137} \mathrm{Cs}$ in the rainbow trout (Oncorhynchus mykiss Walbaum). Wat Res 34:2869-2878 
Bergan TD (1995) Long ecological half-lives of radionuclides in Nordic Limnic. Technical Report EKO-2.3. Nordic Nuclear Safety Research, Norway

Brittain JE, Gjerseth JE (2010) Long-term trends and variation in ${ }^{137} \mathrm{Cs}$ activity concentrations in brown trout (Salmo trutta) from Øvre Heimdalsvatn, a Norwegian subalpine lake. Hydrobiologia 642:107-113

Buesseler K, Aoyama M, Fukasawa M (2011) Impacts of the Fukushima nuclear power plants on marine radioactivity. Environ Sci Technol 45:9931-9935

Buesseler KO, Jayne SR, Fisher NS, Rypina II, Baumann H, Baumann Z, Breier CF, Douglass EM, George J, Macdonald AM, Miyamoto H, Nishikawa J, Pike SM, Yoshida S (2012) Fukushima-derived radionuclides in the ocean and biota off Japan. Proc Natl Acad Sci U S A 109:5984-5988

Chino M, Nakayama H, Nagai H, Terada H, Katata G (2011) Preliminary estimation of release amount of ${ }^{131} \mathrm{I}$ and ${ }^{137} \mathrm{Cs}$ accidentally discharged from the Fukushima Daiichi Nuclear Power Plant into the atmosphere. J Nucl Sci Technol 48:1129-1134

Elliott JM, Hilton JA, Rigg E, Tullett PA, Swift DJ, Leonard DRP (1992) Sources of variation in post-Chernobyl radiocesium in fish from two Cumbrian lakes (north-west England). J Appl Ecol 29:108-119

Folsom TR, Mohanroa GJ, Pillai KC, Screekomaran C (1968) Distribution of Cs-137 in the Pacific Albacore. Report, HASL-197. U.S. Atomic Energy Commission; Health and Safety Laboratory, Washington, DC

Folsom TR, Grismore R (1970) Survey of oceanic fallout traces using cesium absorber. IEEE Trans Nucl Sci 17:202-210

Forseth T, Ugedal O, Jonsson B, Langeland A, Njastad O (1991) Radiocaesium turnover in Arctic charr (Silvalinus alpinus) and brown trout (Salmo trutta) in a Norwegian lake. J Appl Ecol 28:1053-1067

Forseth T, Jonsson B, Naeumann R, Ugedal O (1992) Radioisotope method for estimating food consumption by brown trout (Salmo trutta). Can J Fish Aquat Sci 49:1328-1335

Hakanson L, Anderson T, Nilsson A (1989) Caesium-137 in perch in Swedish lakes after Chernobyl-present situation, relationships and trends. Environ Pollut 58:195-212

Harte J, Holdren C, Schneider R, Shirley C (1991) Toxics A to Z: A Guide to Everyday Pollution Hazards. University of California Press, Berkeley

Kanda J (2013) Continuing ${ }^{137} \mathrm{Cs}$ release to the sea from the Fukushima Dai-ichi Nuclear Power Plant through 2012. Biogeosci Discuss 10:3577-3595

Leung JKC, Shang ZR (2003) Uptake of ${ }^{137} \mathrm{Cs}$ and ${ }^{90} \mathrm{Sr}$ in rice plants. Health Phys 84:170-179

Masson O, Baeza A, Bieringer J, Brudecki K, Bucci S, Cappai M, Carvalho FP, Connan O, Cosma C, Dalheimer A, Didier D, Depuydt G, De Geer LE, De Vismes A, Gini L, Groppi F, Gudnason K, Gurriaran R, Hainz D, Halldórsson O, Hammond D, Hanley O, Holéy K, Homoki Z, loannidou A, Isajenko K, Jankovic M, Katzlberger C, Kettunen M, Kierepko R (2011) Tracking of airborne radionuclides from the damaged Fukushima Dai-lchi nuclear reactors by European networks. Environ Sci Technol 45:7670-7677

Malek MA, Nakahara M, Nakamura R (2004) Uptake, retention and organ/tissue distribution of ${ }^{137} \mathrm{Cs}$ by Japanese catfish (Silurus asotus Linnaeus). J Environ Radioact 77:191-204

Meili M (1991) The importance of feeding rate for the accumulation of radioactive cesium in fish after Chernobyl accident. In: Moberg $L$ (ed) The Chernobyl fallout in Sweden. Swedish Radiation Protection Institute, Stockholm, pp 177-182

Mizuno T, Kubo H (2013) Overview of active cesium contamination of freshwater fish in Fukushima and Eastern Japan. Sci Rep 3:1742

Morgan IJ, Tytler P, Bell MV (1993) The accumulation of cesium-137 from fresh water by alevins and fry of Atlantic salmon and trout. J Fish Biol 43:877-887

Morino Y, Ohara T, Nishizawa M (2011) Atmospheric behavior, deposition, and budget of radioactive materials from the Fukushima Daiichi nuclear power plant in March 2011. Geophys Res Lett 38:L00G11

Peters EL, Schultz IR, Newman MC (1999) Rubidium and cesium kinetics and tissue distribution in channel cattish (Ictalurus punctarus). Ecotoxicology 8:287-300

Pröhl G, Ehlken S, Fiedler I, Kirchner G, Klemt E, Zibold G (2006) Ecological halflives of ${ }^{90} \mathrm{Sr}$ and ${ }^{137} \mathrm{Cs}$ in terrestrial and aquatic ecosystems. J Environ Radioact 91:41-72

Rainbow PS (2007) Trace metal bioaccumulation: models, metabolic availability and toxicity. Environ Int 33:576-582

Rowan DJ, Rasumussen JB (1995) The elimination of radiocesium from fish. J Appl Ecol 32:739-744

Smith JT, Sasina NV, Kryshev Al, Belova NV, Kudelsky AV (2009) A review and test of predictive models for the bioaccumulation of radiostrontium in fish. J Environ Radioact 100:950-954
The Fisheries Agency of the Japanese Government (2014a) Results of the inspection on radioactivity materials in fisheries products., http://www.jfa. maff.go.jp/e/inspection/index.html (accessed 2014.5.25)

The Fisheries Agency of the Japanese Government (2014b) Report on the monitoring of radionuclides in fishery product (March 2011-March 2014)., http://www.mofa.go.jp/files/000040303.pdf (accessed 2014.6.4)

Travnikova IG, Bazjukin AN, Bruk GL, Shutov VN, Balonov MI, Skuterud L, Mehli H, Strand P (2004) Lake fish as the main contributor of internal dose to lakeshore residents in the Chernobyl contaminated area. J Environ Radioact 77:63-75

Ugedal O, Jonsson B, Njåstad O, Næumann R (1992) Effects of temperature and body size of radiocesium retention in brown trout (Salmo trutta). Freshwat Biol 28:165-171

Ugedal O, Forseth T, Jonsson B, Njåstad O (1995) Sources of variation in radiocesium levels between individual fish from a Chernobyl contaminated Norwegian lake. J Appl Ecol 32:352-361

Whicker FW, Schultz V (1982) Radioecology: nuclear energy and the environment, vol II. CRC Press Inc, Boca Raton, FL

Whicker FW, Hinton TG, Niquette DJ, Seel J (1993) Health risk to hypothetical residences of a radioactively contaminated lake bed. In: Proceedings of the ER '93 Environmental Remediation Conference "Meeting the Challenge", vol 1. U.S. Department of Energy, Augusta, GA, pp 619-624

Yasunari TJ, Stohl A, Hayano RS, Burkhart JF, Eckhardt S (2011) Cesium-137 deposition and contamination of Japanese soils due to the Fukushima nuclear accident. Proc Natl Acad Sci U S A 108:19447-19448

Young DR, Folsom TR, Hodge VF $(1975){ }^{137} \mathrm{Cs}$ and ${ }^{40} \mathrm{~K}$ in the flesh of pacific albacore, 1964-1974. Health Phys 29:689-694

doi:10.1186/2193-1801-3-479

Cite this article as: Arai: Radioactive cesium accumulation in freshwater

fishes after the Fukushima nuclear accident. SpringerPlus 2014 3:479.

\section{Submit your manuscript to a SpringerOpen ${ }^{\odot}$ journal and benefit from:}

- Convenient online submission

- Rigorous peer review

- Immediate publication on acceptance

- Open access: articles freely available online

- High visibility within the field

- Retaining the copyright to your article

Submit your next manuscript at $\gg$ springeropen.com 